\title{
IAMJ
}

INTERNATIONAL

AYURVEDIC

MEDICAL JOURNAL

\section{A PHARMACEUTICO ANALYTICAL STUDY OF TILANALA KSHARASUTRA}

\section{$\underline{\text { Radhakrishna Reddy } D^{1}}$, Ravi R Chavan ${ }^{2}$, Shankara gowda ${ }^{3}$}

$3^{\text {rd }}$ Year P.G Scholar ${ }^{1}$, Associate Professor ${ }^{2}$, Professor and H.O.D ${ }^{3}$;

Dept of Rasashastra \& Bhaishajya Kalpana, Taranath Govt. Ayurvedic Medical College, Ballari, Karnataka, India

Corresponding Author: drrkreddy19@gmail.com

https://doi.org/10.46607/iamj1408102020

(Published online: October 2020)

Open Access

(C) International Ayurvedic Medical Journal, India 2020

Article Received: 19/09/2020 - Peer Reviewed: 29/09/2020 - Accepted for Publication: 05/10/2020

Check for updates

\begin{abstract}
Kshara kalpana (Alkali preparations) is an alkaline herbo-mineral formulation widely used in Ayurvedic Pharmaceutico-therapeutics. Since Ksharasutra has been used widely in Ayurvedic clinical practice specially in Ano rectal pathological conditions. Though Apamarga is most widely used seasonal plant for the preparation of Ksharasutra which is the standard one, the drugs used for the preparation of such standard Kalpana need not to be limited to certain drugs hence in the present study Tilanala has been selected. Aim and objective: The main aim of the study was preparation of Tilanala Ksharasutra as per the classics and physico chemical analysis of Tilanala Ksharasutra. Materials and Methods: Tilanala Ksharasutra was prepared by 11 coatings of Snuhi Ksheera, 7 coatings of Tilanala Kshara, 3 coatings of Haridra Churna and which were kept under UV light for the purpose of sterilization later it was stored in airtight glass tubes and labelled. The physico chemical analysis of Plain Barbour's surgical thread, Tilanala Ksharasurtra and Tilanla Kshara were done. Results: pH of Tilanala Ksharasutra is 9.65(+/-)0.10 and percentage of sodium, potassium, curcumin, turmeric, euphol and total alkalis present in Tilanala Ksharasutra are $2.04 \%, 21.79 \%, 0.039 \%, 3.06 \%, 2.25 \%, 22.64 \%$ respectively. Discussion and Conclusion: Tilanla Ksharasutra is not only indicated in Fistula-in-ano but also indicated in Pilonoidal sinus, haemorrhoid etc., To gain the acceptance of the treatment at the global level present study was focused on standard operative procedure i.e., pharmaceutical and analytical study and exploring other drugs for the preparation of such magical Kalpana i.e., Ksharasutra.
\end{abstract}


Keywords: Tilanala Kshara, Tilanala Ksharasutra, TLC

\section{INTRODUCTION}

Rasashastra and Bhaishajya Kalpana is a branch of Ayurveda which has given great emphasis to the comprehensive knowledge of both mineral and herbal drugs, preparation, preservation and dispensing of the preserved drugs with preclinical and clinical standardization. In present study Tilanala is chosen, according to Acharya ${ }^{[1]}{ }_{-}$Mushka, Yava, Palasha, Svarjika and Tila are mentioned under Kshara panchaka and Sudha (Snuhi), Palasha, Shikhara, Chincha, Arka, Tilanala, Svarjika, Yava are mentioned under Kshara ashtaka ${ }^{[2]}$ and due to its easy availability in the present study Apamarga Kshara is replaced with Tilanala Kshara in the preparation of Ksharasutra (medicated thread), as it is easily and abundantly available hence Tilanala Ksharasutra is undertaken. The analytical study reveals the chemical composition of the formulations as well as their concentration. By this it helps to ensure safety limits and accuracy of the drug. Physico-chemical analysis of the drugs is carried out by using current analytical methodologies for understanding and interpretation of physico-chemical changes occurring during and after pharmaceutical processing. The physico-chemical analysis of Tilanala Kshara, Tilanala Ksharasutra and plain surgical Babour's thread was done.

\section{Materials and Methods}

Pharmaceutical stride involved in preparation of Tilanala Ksharasutra

- Preparation of Tilanala Kshara.

- Preparation of Tilanala Ksharasutra.

- Packing and labelling

\section{Preparation of Tilanala Kshara:}

Table 1: Table showing list of drugs with Quantity

\begin{tabular}{|l|l|l|}
\hline Si. No & Drug Name & Quantity \\
\hline 1. & Burnt Tilanala ash & $1.91 \mathrm{~kg}(12$ ser $)$ \\
\hline 2. & Water & 72 litres \\
\hline
\end{tabular}

$37.5 \mathrm{kgs}$ of completely dried Tilanala was burnt into ashes to obtain $1.91 \mathrm{kgs}$ of Tilanala ash. $1.91 \mathrm{kgs}$ of Ash of Tilanala was added with 6 parts of water i.e., 72 litres of water and was stirred well and left overnight without disturbing it. Next day this is filtered through double layered cora cloth and the same was repeated for another 20 times to obtain a Gomutra Varna (cow's urine colour) filtrate. The obtained Gomutra varna filtrate was subjected for boiling over mild heat in a clean stainless-steel vessel till it attained semi solid consistency and continuous stirring was done so that Kshara should not stick to the vessel. The final product is an ivory white powder, but it was coarse and dry. Hence it was taken in a small clean Khalwayantra and made it very fine powder and immediately stored in airtight glass container.

\section{Observation:}

- Time taken for whole procedure 12 hours 30 minutes

- Colour of the filtrate - Gomutra varna

- Colour of the Kshara in semisolid form was - Light green colour

- Colour of the Tilanala kshara_- Ivory white powder form

- Quantity of Tilanala kshara_obtained- 608 grams

- $\quad \mathrm{p}^{\mathrm{H}}$ of the obtained Kshara- $11 \mathrm{p}^{\mathrm{H}}$ 


\section{Preparation of Tilanala Ksharasutra:}

Table 2: Table showing list of drugs with Quantity

\begin{tabular}{|l|l|l|}
\hline SI no & Drug Name & Quantity \\
\hline 1. & Snuhi ksheera (latex of euphorbia neriifolia) & $2307 \mathrm{ml}$ for 21 coatings \\
\hline 2. & Tilanala kshara(alkali of sesamum indicum) & $596 \mathrm{gms}$ for 7 coatings \\
\hline 3. & Haridra choorna(fine powder of curcuma longa) & $463 \mathrm{gms}$ for 3 coatings \\
\hline
\end{tabular}

\section{Method of Preparation}

Surgical Barbour's thread No. 20 is tied though out the length of the hanger. The freshly collected Snuhi Ksheera was smeared on thread equally throughout its length and hanger will be dried in cabinet. This process is repeated for 10 more days. On $12^{\text {th }}$ day thread will be smeared with Snuhi Ksheera and then hanger is passed through heap of fine powder of Tilanala Kshara, and then dried in cabinet. The same procedure was repeated for 6 more days. On $19^{\text {th }}$ day the thread will be smeared with Snuhi Ksheera and passed through heap of fine powder of Haridra Churna and dried in cabinet. The procedure was repeated for 2 more days. Lastly the prepared Ksharasutra was kept in Ksharasutra cabinet for $1 \mathrm{hr}$. under U.V. light radiation for sterilization.

Totally 16 hangers were taken and labelled as Tilanala Ksharasutra hangers, each hanger has 25 notches on either side, hence each hanger can accommodate 50 threads. In total 800 Ksharasutras were prepared at once.

After complete drying of the threads the threads were packed in airtight glass test tubes the tubes were labelled.

\section{Observation}

- Colour of the plain thread- white.

- Colour of the thread after Snuhi Ksheera application - white.

- There was increased in thickness and stiffness of the thread after Snuhi Ksheera application.

- Colour of the thread after Kshara application white.

- Small crystals were noticed on the thread with increased thickness and stiffness.

- Colour of the thread after application of Haridra churna - immediately - yellow as Haridra.

- Later in few minutes it turned - maroon red.

- Length of the thread - 30, 20 and $15 \mathrm{cms}$ respectively, according to the need of the surgeon and was folded and sealed in the airtight glass test tubes and labelled accordingly.

- Quantity of Snuhi Ksheera used for 21 days for 16 hangers is $2307 \mathrm{ml}$.

- Quantity of Tilanala Kshara used for 7 days for 16 hangers is 596 gms.

- Quantity of Haridra Churna used for 3 days for 16 hangers is 463 gms.

Table 3: Showing Analytical results of untreated thread, Tilanala Kshara and Tilanala Ksharasutra

\begin{tabular}{l|l|l|l|}
\hline A. Physico-chemical parameters & \multicolumn{3}{l}{} \\
\hline Parameters & Untreated thread & Tilanala Kshara & Tilanala Kshara Sutra \\
\hline Length & $31.6 \mathrm{~cm}$ & - & $31.6 \mathrm{~cm}$ \\
\hline Weight & $0.0791 \mathrm{gm}$ & - & $0.5733 \mathrm{gm}$ \\
\hline Diameter & $0.81 \mathrm{~mm}$ & - & $1.91 \mathrm{~mm}$ \\
\hline Tensile strength & $6.235 \mathrm{~kg}$ & - & $4.975 \mathrm{~kg}$ \\
\hline Loss on Drying at $105^{\circ} \mathrm{C}$ & $0.21 \%$ & $3.67 \%$ & $4.97 \%$ \\
\hline Total ash & $0.35 \%$ & $89.25 \%$ & $59.93 \%$ \\
\hline Acid insoluble ash & $0.01 \%$ & $2.17 \%$ & $6.57 \%$ \\
\hline Water soluble ash & $0.05 \%$ & $2.57 \%$ & $15.76 \%$ \\
\hline Sulphated ash & $0.12 \%$ & $67.23 \%$ & $54.32 \%$ \\
\hline Hexane soluble extractives & $1.22 \%$ & - & $10.18 \%$ \\
\hline Water soluble extractives & $0.26 \%$ & - & $61.85 \%$ \\
\hline
\end{tabular}




\begin{tabular}{|l|l|l|l|}
\hline $\begin{array}{l}\text { pH }(1 \% \text { aqueous solution }) \\
\text { B. Quantitative estimation }\end{array}$ & $6.65(+/-) 0.10$ & $10.98(+/-) 0.10$ & $9.65(+/-) 0.10$ \\
\hline & Untreated Thread & Tilanala Kshara & Tilanala Ksharasutra \\
\hline Sodium & $0.05 \%$ & $2.68 \%$ & $2.04 \%$ \\
\hline Potassium & $1.24 \%$ & $29.43 \%$ & $21.79 \%$ \\
\hline Curcumin & - & - & $0.039 \%$ \\
\hline Turmeric & - & - & $3.06 \%$ \\
\hline Euphol & - & - & $2.25 \%$ \\
\hline Total alkalis & - & $26.63 \%$ & $22.64 \%$ \\
\hline
\end{tabular}

Table 4: Showing Microbial contamination

\begin{tabular}{|l|l|l|l|}
\hline & Untreated thread & Tilanala Kshara & Tilanala Ksharasutra \\
\hline Total aerobic count & Nil & Nil & Nil \\
\hline Total fungal count & Nil & Nil & Nil \\
\hline
\end{tabular}

\section{Thin Layer Chromatography}

Solvent System: n-Hexane: Ethyl Acetate: 70:30

Note: The Rf value of curcumin (CC) and euphol (EU) were respectively noted as 0.45 and 0.37 . Both of these were noted present in alcoholic extracts of Tilanala Kshara Sutra. Any spot was not observed in Tilanala $k s h a r a(T N K)$ for given solvent system.

\section{DISCUSSION}

$72 \mathrm{kgs}$ of collected wet Tilanala took around 45 days to dry. Collected Tilanala when dried completely gave only $52.08 \%$ and ash obtained to that of wet Tilanala is $02.65 \%$, percentage of ash obtained to that dry Tilanala is $05.09 \%$.

- Percentage of Kshara obtained to that of wet and dry Tilanala is $0.84 \%, 1.62 \%$ respectively. So, it shows that every $1 \mathrm{~kg}$ of wet Tilanala gives 8.4 gms of Tilanala Kshara, and that to dry Tilanala gives 16.20 gms of Tilanala Kshara.

- After Haridra churna application the colour of the threads was yellow, smooth and even, within few minutes the colour of the threads changed to maroon red colour because the rhizome contains active curcumin compounds and some organic acids. When these stems are dried and powdered, their concentration increases. When this powder is dissolved in water and a pinch of lime, the organic acids are neutralised by alkaline lime. As a result, the yellow Xanthophyll is supressed, and the organe-red carotene pigment becomes more prominent, so turmeric turns red ${ }^{[3]}$. The reason behind the storage in airtight glass material is Kshara is highly hygroscopic in nature and by storing in airtight glass jar increases the shelf life of the product ${ }^{[4]}$. Most of Shodana dravya mentioned for Snuhi Ksheera Shodana are acidic in nature and the Snuhi ksheera is slightly alkaline in nature and hence when Shodana is done the Teekshna (penetrating) property of Snuhi decreases which in turn decreases the cutting property of Snuhi Ksheera which is a prime factor for Ksharasutra. Snuhi Ksheera when used abundantly causes toxicity, but Ksheera used in preparation of Ksharasutra is in minimum quantity so it acts as nectar in this disorder.

\section{Reason behind 21 coatings of application ${ }^{[5]}$}

As Kshara is very hygroscopic in nature and if only 7 layers Kshara is applied Kshara melts easily hence to prevent the exposure of Kshara to the atmospheric $\mathrm{H}_{2} \mathrm{O}$ our Acharyas have explained 3 layers of Haridra coatings, not only this Haridra churna is said to be best Vrana Shodana(wound debriding), Ropana(healing) and also has bacteriostatic, bactericidal effect and also has Varnya (depigmenting) property so that there would be less scar left over after Ksharasutra therapy present researches workers have standardized to 21 days. And as observed any other number of applications can be done, but 21 layers application fits the lumen of the average fistulous tract appropriately, whereas a greater number of applications increases the diameter of the thread which in turn becomes difficult during Ksharasutra changing. 
Weight of the thread - weight of untreated was 0.0791 gms, after 21 coatings the weight of Tilanala Ksharasutra was - $0.5733 \mathrm{gm}$, it was slightly less might be because of hygroscopic property of Tilanala Kshara seemed to be higher which absorbed the atmospheric $\mathrm{H}_{2} \mathrm{O}$ and hence melts the thin layer of Tilanala hence weight decreased.

Diameter - Due to Application of medicaments on the diameter of the thread increases and the diameter of untreated thread, Tilanala Ksharasutra are $0.81 \mathrm{~mm}, 1.91$ $\mathrm{mm}$ respectively. The reason for diameter of Tilanala Ksharasutra is less because of hygroscopic nature of the Tilanala Kshara.

Tensile strength of the thread - The tensile strength of untreated thread, Tilanala Ksharasutra are $6.235 \mathrm{~kg}$, $4.762 \mathrm{Kg}$ respectively because of corrosive nature of the Kshara when applied to thread weakens the tensile strength of the thread.

Loss on drying of the threads - LOD of untreated thread, Tilanala Kshara and Tilanala Ksharasutra are $0.21 \%, 3.67 \%$ and $4.97 \%$ respectively this is also because of hygroscopic nature of the Kshara.

Water Soluble extractives - Water Soluble extractives of untreated thread, Tilanala Ksharasutra are $0.26 \%$ and $61.85 \%$ respectively due to presence of Kshara and Haridra churna which are easily soluble in water. And the rest of thread and thickened part of Snuhi Ksheera are said to be insoluble. The percentage of water-soluble extractives shows that the coated material can easily dissolve in bodily fluids.

$\mathbf{p H}-\mathrm{pH}$ of untreated thread, Tilanala Kshara, Tilanala Ksharasutra are $6.65 \pm 0.10,10.98 \pm 0.10$ and $9.65 \pm 0.10$ respectively. Decrease in the $\mathrm{pH}$ of Tilanala Ksharasutra might be because of the other coatings over the Kshara.

Quantitative Analysis of Tilanala Kshara: Percentage of sodium, potassium and total alkalis present in Tilanala Kshara are 2.68\%, 29.43\% and 34.12\% respectively. Potassium was significantly high in Tilanala Ksharasutra.

Quantitative Analysis of Tilanala Kshara sutra: Percentage of sodium, potassium, curcumin, turmeric, Euphol and total alkalies present in Tilanala
Ksharasutra are $2.04 \%, 21.79 \%, 0.039 \%, 3.06 \%$, $2.25 \%, 22.64 \%$ respectively.

Microbial contamination - Microbial contamination i.e., total aerobic count and total fungal count of Tilanala Kshara and Tilanala Ksharasutra were nil, alkaline property of Kshara does not allow any organism to grow and also all the Ksharasutras were exposed to UV light and also packing was done in all aseptic precautions.

Thin Layer Chromatography - TLC of Tilanala Ksharasutra showed presence of curcumin and euphol and $\mathrm{R} \mathrm{f}$ values of these are 0.45 and 0.37 respectively.

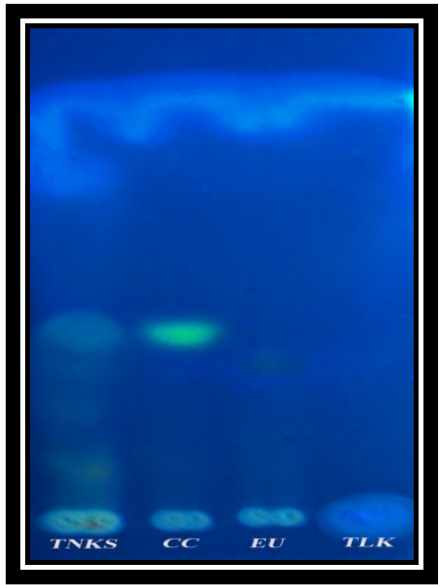

Fig.1: Showing TLC of Tilanala Ksharasutra

\section{CONCLUSION}

The ICMR has validated the Ksharasutra therapy and is also under active consideration of the WHO for its globalization ${ }^{[6]}$. This type of therapy is considered as a minimal invasive parasurgical measure at global level. The Ksharasutra which is used in this prime treatment modality has to be prepared according to the standard operative procedure and standard analytical parameters need to be followed hence in the present study the Tilanala Ksharasutra is prepared according to the standard operative procedure and standard analytical parameters were followed.

\section{REFERENCES}

1. Sharma Sadananda. Rasa Tarangini. Edited by Kasinatha Shastri. 11 $1^{\text {th }}$ Edition. Varanasi: Motilal Banarasi Das; $1979.2^{\text {nd }}$ Taranga, Verses 7, 12 pp. 
2. Sharma Sadananda. Rasa Tarangini. Edited by Kasinatha Shastri. 11 ${ }^{\text {th }}$ Edition. Varanasi: Motilal Banarasi Das; 1979.2 ${ }^{\text {nd }}$ Taranga, Verse 8, $12 \mathrm{pp}$.

3. G. G. Saraswat, Delhi Why does turmeric powder turn red in colour when it is heated with lime? [Internet] Times of India 2003[cited 23 November 2003 07:42 AM IST] Available from: https://timesofindia.indiatimes.com/Why-doesturmeric-powder-turn-red-in-colour-when-it-isheated-with-lime/articleshowprint/297371.cms

4. Anonymous. Rasa tantra saara va siddha prayoga sangraha. $17^{\text {th }}$ edition. Ajmir: Krishna Gopala Ayurveda bhavana ;2006, Prathama Khanda, 7pp.

5. S. K. Sharma, K. R. Sharma, Kulwant Singh. kshara sutra therapy in fistula-in-ano and other ano-rectal disorders, New Delhi: Rashtriya Ayurved Vidyapeeta 1994-95, 45-46pp.

6. Dr Shivalingappa Arakeri "Management of Complex Recto-Vaginal Fistula By An Ayurvedic Surgical Approach - A Rare Case Report." IOSR Journal of Dental and Medical Sciences (IOSRJDMS), vol. 17, no. 11, 2018, pp 76.

\section{Source of Support: Nil \\ Conflict of Interest: None Declared}

How to cite this URL: Radhakrishna Reddy D et al: A Pharmaceutico Analytical Study Of Tilanala Ksharasutra. International Ayurvedic Medical Journal \{online\} 2020 \{cited October, 2020 $\quad$ Available from: http://www.iamj.in/posts/images/upload/4656_4661.pdf 